\title{
Tree community dynamics of a northern Minas Gerais seasonally dry forest
}

\author{
Geovany Heitor Reis ${ }^{1 *}$, Rubens Manoel dos Santos ${ }^{1}$, Diego Gualberto Sales Pereira ${ }^{2}$,
} Jean Daniel Morel ${ }^{1}$, Paola Ferreira Santos ${ }^{2}$

10.1590/0034-737X201865030003

\begin{abstract}
This study aimed to characterize the dynamics, structural changes and floristics of a Northern Minas Gerais Seasonally Deciduous Forest tree community, in a 5 year interval. In 2005, $10(20$ x 20m) plots were allocated. All trees $(\mathrm{CBH}>10 \mathrm{~cm})$ were tagged and measured. A second census was carried out in $2010 \mathrm{in}$ order to measure surviving, new recruits and dead trees. In 2005, 46 species were recorded, moving to 45 in 2010. No significant differences were found for Shannon - diversity $\left(\mathrm{H}^{\prime}=2.62\right.$ nats ind ${ }^{-1}$ in $2005 ; \mathrm{H}^{\prime}=2.60$ nats ind $^{-1}$ in 2010) and Pielou eveness $(\mathrm{J}=0.683$ in 2005 ; $\mathrm{J}=0.682$ in 2010) in the interval. A total of 57 dead records (rate of $1.64 \%$ year $^{-1}$ ) were found whereas 18 trees were recruited (rate of $0.53 \%$ year $^{-1}$ ). Despite the higher mortality as compared to recruitment, the results suggest that the community remained stable in both structural and diversity terms in the interval considered.
\end{abstract}

Keywords: forest dynamics; temporal variation; deciduous forest; ecotonal region.

\section{RESUMO}

\section{Dinâmica da comunidade arbórea de uma floresta estacional decidual no norte de Minas Gerais.}

Este estudo objetivou caracterizar a dinâmica, além das mudanças estruturais e florísticas em uma comunidade arbórea de Floresta Estacional Decidual, no Norte de Minas Gerais no intervalo de cinco anos. Em 2005, foram alocadas 10 parcelas de 20x20m. Os indivíduos com CAP > $10 \mathrm{~cm}$ foram marcados com etiquetas numeradas e mensurados. Em 2010, no segundo inventário, foram incorporados os recrutas, registrados os mortos e remedidos os sobreviventes. Em 2005 foram registradas 46 espécies, e em 2010 foram 45 espécies. O índice de Shannon-Wienner $\left(\mathrm{H}^{\prime}=2,62 \mathrm{nats}^{\mathrm{n}} \mathrm{nd}^{-1} \mathrm{em}\right.$ $2005 ; H^{\prime}=2,60$ nats ind $\left.{ }^{-1} \mathrm{em} 2010\right)$ e a equabilidade de Pielou $(\mathrm{J}=0,683 \mathrm{em} 2005 ; \mathrm{J}=0,682 \mathrm{em} 2010)$ não apresentaram diferenças significativas. Foram registrados ao todo 57 indivíduos mortos, com taxa de mortalidade média de 1,64\% $\mathrm{ano}^{-1}$. Enquanto ocorreram 18 recrutas, apresentando taxa de recrutamento médio de 0,53\% ano ${ }^{-1}$. Apesar da maior mortalidade, em comparação com o recrutamento, os resultados sugerem que a comunidade se manteve estável tanto em termos estruturais e de diversidade no intervalo considerado.

Palavras-chave: dinâmica florestal; variações temporais; florestas decíduas; região ecotonal.

\footnotetext{
Submitted on December 22 ${ }^{\text {nd }}, 2015$ and accepted on April 09th, 2018.

${ }^{1}$ Universidade Federal de Lavras, Departamento de Ciências Florestais, Lavras, Minas Gerais, Brazil. geovanyreis@gmail.com; rubensmanoel@dcf.ufla.br; morel.jean@gmail.com ${ }^{2}$ Universidade Federal de Lavras, Departamento de Biologia, Lavras, Minas Gerais, Brazil. diegogspereira@gmail.com; paoolapaz@yahoo.com.br

*Corresponding author: geovanyreis@gmail.com
} 


\section{INTRODUCTION}

Tropical forests are characterized by high floristic diversity, structural and dynamics complexity driven by environmental shifts in both space and time (Oldeman, 1990; Murphy \& Bowman, 2012; Cavaleri et al., 2015). Due to Tropical Forest complexity, functional and successional process such as growth, reproduction and nutrient cycling can be distinguished between Seasonally Forests and Ombrophilous Forests once the former are submitted to a water deficit period (Murphy \& Lugo, 1986; Pennington et al., 2006; Apgaua et al., 2015). Climate is a key factor in Seasonally Forests distribution since they are mainly submitted to a markedly opposing, well-defined rainy and dry seasons. In addition to climate, edaphic and relief variation are also important in a finer scale for their distribution (Murphy \& Lugo, 1986; Pennington et al., 2009; Apgaua et al., 2015).

Brazilian Seasonally Deciduous Forests can commonly be found in Northern Minas Gerais and Central Brazil in both Caatinga and Cerrado domains (IBGE, 2012; Santos et al., 2012). In the Northern Minas Gerais, they usually lie in ecotonal regions presenting high beta diversity (Santos et al., 2012; Apgaua et al., 2014a; b). According to Apgaua et al., (2014b), conservation efforts should be given to these areas as their tree component are important in maintaining ecosystem functions, acting as sources of seeds and propagules to other areas as well as keeping the organic matter cycling which in turn sustains soil fertility. In this last case, it is worth highlighting that it is the very soil fertility that cause these areas to be prone to perturbations from agriculturerelated activities (Pennington et al., 2006; Santos et al., 2017).

Because of the continuous risk of anthropic perturbations, studies focusing these communities may be useful for elaborating conservation strategies for the forest remnants. Forests patches of these regions have been studied in the last years, mainly focused on their floristic composition, diversity, structure and distribution (Santos et al., 2007; Santos et al., 2008; Santos et al., 2011; Santos et al., 2012; Apgaua et al., 2014a; b). However, to date, few studies focused on temporal structural changes and dynamics of these tree communities have been reported. In this sense, the purpose of this work was to obtain new information on the demographic and structural changes of the arboreal component of tropical deciduous forests in order to contribute to the expansion of this knowledge, which is still considered a scientific gap. Therefore, our aim is to analyze the tree dynamics of a Northern Minas Gerais Seasonally Deciduous Forest in a 5-year interval.

\section{MATERIALS AND METHODS}

\section{Study area}

The study was carried out in a 10 ha remnant of a Seasonal Deciduous Forest (sensu IBGE, 2012) in the municipality of Juvenilia, Minas Gerais, in the coordinates $14^{\circ} 32^{\prime} 68^{\prime \prime} \mathrm{S}$ and $44^{\circ} 12^{\prime}$ '63" W. According to Koeppen classification, the climate is As (Tropical with dry-summer) with mean annual temperatures of $23^{\circ} \mathrm{C}$ and mean annual precipitation of $1000 \mathrm{~mm}$, and the rainy season being more concentrated from November to January (Santos et al., 2011).

\section{Sampling}

In 2005 , ten $20 \times 20 \mathrm{~m}$ permanent plots were allocated along the forest fragment, distributed in a transect running parallel to the longer axis length. Paired plots were distributed each $20 \mathrm{~m}$ along the transect, separated $10 \mathrm{~m}$ of each other (Santos et al., 2008). All trees with CBH (Circumference at Breast Height) $>10 \mathrm{~cm}$ were recorded with numbered aluminum tags and measured. In 2010, a second census was carried out for remeasuring surving trees, counting dead records and new recruits reaching the minimum $\mathrm{CBH}$ criteria. New recruits were tagged, identified to species level and had their $\mathrm{CBH}$ recorded.

\section{Phytosociological and Floristic composition}

In order to describe tree community for each census (2005 and 2010), the following descriptors were employed: richness, absolute and relative density, basal area, absolute and relative dominance, absolute and relative frequency and importance value (Kent \& Coker, 1992). Species diversity and dominance were calculated for each census by the Shannon Index ( $\left.\mathrm{H}^{\prime}\right)$ and Pielou eveness (J') (Magurran 2004). Richness and diversity were compared for each census by means of rarefaction curves. In order to analyze structural changes, T-tests for independent samples were used to compare density and basal area between censuses, following Magurran (2004).

Diameter sizes classes were created by using increasing size bins ( $1^{\mathrm{a}}$ class: $3-5.9 \mathrm{~cm} ; 2^{\mathrm{a}}$ class: $6-11.9$ $\mathrm{cm} ; 3^{\mathrm{a}}$ class: $12-23.9 \mathrm{~cm} ; 4^{\mathrm{a}}$ class $24-47.9 \mathrm{~cm} ; 5^{\mathrm{a}}$ class: > $48 \mathrm{~cm}$ ). Observed and expected diameter distributions for each census were statistically compared by Qui-Square test. To test for differences in diameter distribution between the censuses, the G-test was used.

\section{Dynamics}

Mean annual rates were used to calculate tree dynamics by using mortality $\left(\mathrm{M}=\left(1-\left[\left(\mathrm{N}_{0}-\mathrm{N}_{\mathrm{m}}\right) / \mathrm{N}_{0}\right] 1 / \mathrm{t}\right) * 100\right)$ and recruitment $\left(\mathrm{R}=\left(1-\left(1-\mathrm{N}_{\mathrm{r}} / \mathrm{N}_{\mathrm{t}}\right) 1 / \mathrm{t}\right) * 100\right.$ rates, whereas biomass dynamics were described by basal area loss $(\mathrm{P}=$ $\left.\left(1-\left(\left(\mathrm{AB}_{0}-\left(\mathrm{AB}_{\mathrm{m}}+\mathrm{AB}_{\mathrm{d}}\right)\right) / \mathrm{AB}_{0}\right) 1 / \mathrm{t}\right) * 100\right)$ and gain $(\mathrm{G}=(1$ 
- $\left.\left.\left(1-\left(\mathrm{AB}_{\mathrm{r}}+\mathrm{AB}_{\mathrm{g}}\right) / \mathrm{AB}_{\mathrm{t}}\right) 1 / \mathrm{t}\right) * 100\right)$, where: $\mathrm{t}$ is the time elapsed between censuses; $\mathrm{N}_{0}$ and $\mathrm{N}_{\mathrm{t}}$ the initial and final tree counts; $\mathrm{N}_{\mathrm{m}}$ and $\mathrm{N}_{\mathrm{r}}$ are dead trees and recruit counts; $\mathrm{AB}_{0}$ and $\mathrm{AB}_{\mathrm{t}}$ are the initial and final tree basal area; $\mathrm{AB}_{\mathrm{m}}$ is the basal area of dead trees; $\mathrm{AB}_{\mathrm{r}}$ is basal area of recruits; and $\mathrm{AB}_{\mathrm{d}}$ and $\mathrm{AB}_{\mathrm{g}}$ are the increment and decrement in basal area from the surviving trees (Sheil et al., 1995; 2000).

Overall dynamics were described by tree $\left(\mathrm{T}_{\mathrm{N}}=(\mathrm{M}+\right.$ $\mathrm{R}) / 2)$ and basal area $\left(\mathrm{T}_{\mathrm{AB}}=(\mathrm{P}+\mathrm{G}) / 2\right)$ turnover rates from the mean mortality and recruitment, and loss and gain rates as previously described (Oliveira-Filho et al., 1997; Werneck \& Franceschinelli, 2004). Additionally, net changes rates were obtained for each period for both trees $\left(\mathrm{Ch}_{\mathrm{N}}=\left[\left(\mathrm{N}_{\mathrm{t}} / \mathrm{N}_{0}\right) 1 / \mathrm{t}-1\right] \times 100\right)$ and basal area $\left(\mathrm{Ch}_{\mathrm{AB}}=\right.$ $\left.\left[\left(\mathrm{AB}_{\mathrm{t}} / \mathrm{AB}_{0}\right) 1 / \mathrm{t}-1\right] \times 100\right)($ Korning \& Balslev, 1994).

\section{Gradient analysis}

A Detrended Correspondence Analysis (DCA) was performed for each census. Two abundance matrices were obtained, one for each census (2005 and 2010). The software PC-Ord 5 (McCune \& Mefford, 2006) was used to run the analysis.

\section{RESULTS}

\section{Floristic and phytosociological composition}

In 2005, 46 species were recorded, belonging to 40 genera and 16 families and 45 species, 40 genera and 16 families for the 2010 census (Table 1). The main species in terms of importance value (IV) practically kept their ranking in the interval analyzed. The 10 main species ordered by IV in both censuses were Eugenia uniflora L., Pseudopiptadenia contorta (DC.) G.P.Lewis \& M.P.Lima, Poincianella pluviosa (DC.) L.P.Queiroz, Handroanthus ochraceus (Cham.) Mattos, Terminalia phaeocarpa Eichler, Commiphora leptophloeos (Mart.) Gillett, Handroanthus impetiginosus (Mart. ex DC.) Mattos, Combretum duarteanum Cambess., Myracrodruon urundeuva Fr. All. and Ruprechtia laxiflora Meisn. These species accounted for $69.63 \%$ and $69.30 \%$ of the total IV for 2005 and 2010 respectively. Only one position changed in the IV ranking as showed by P. pluviosa ( $3^{\mathrm{a}}$ in 2005 to $4^{\mathrm{a}}$ in 2010) and H. ochraceus ( $4^{\mathrm{a}}$ in 2005 to $3^{\mathrm{a}}$ in 2010).

Richness ( $\mathrm{S}=46$ in 2005; $\mathrm{S}=45$ in 2010; Figure 1) and diversity $\left(H^{\prime}=2.62\right.$ nats ind $^{-1}$ in $2005 ; H^{\prime}=2.60$ nats $^{\prime}$ d $^{-1}$ in 2010; Figure 2) were similar for both censuses and were not significantly different as suggested by the rarefactions curves.

Likewise, Pielou evenness $(\mathrm{J}=0.683$ in $2005 ; \mathrm{J}=0.682$ in 2010) was practically unaltered. Tree density changed from 1845 ind ha-1 in 2005 to e 17025 ind ha-1 in 2010, showing a significant reduction $(\mathrm{t}=2.258 ; \mathrm{p}=0.028)$. However, basal area presented the opposite pattern and increased in the interval $(\mathrm{t}=-2.172 ; \mathrm{p}=0.035)$, changing from $7.66 \mathrm{~m}^{2}$ in 2005 to $8.30 \mathrm{~m}^{2}$ in 2010 (Table 2).

The observed frequency distribution by diameter classes showed significant differences from the expected for $2005\left(X^{2}=518.847 ; p<0.0001\right)$. In addition, the diameter distribution was significantly different between 2005 and 2010 (Figure 3). In both censuses, the second class (6 $11.9 \mathrm{~cm})$ presented the highest number of individuals. Nevertheless, the first class $(3-5.9 \mathrm{~cm})$ was reduced by $20 \%$ in the number of individuals and the second by $4.25 \%$. The third $(12-23.9 \mathrm{~cm})$ and fourth $(24-47.9 \mathrm{~cm})$ classes increased by $5.55 \%$ and $45 \%$ respectively. The fifth class $(>48 \mathrm{~cm}$ ) remained with a single individual.

\section{Dynamics}

Abundance was reduced from 720 in 2005 to 681 in 2010 as mortality was higher than recruitment in the sampling interval. Dead records reached a total of 57 individuals with a rate of $1.64 \%$ year $^{-1}$ (Table 2). Species with high mortality rates were Eugenia uniflora (14 individuals), Pseudopiptadenia contorta (13) and Combretum duarteanum (9). A total of 18 individuals were recruited, reaching a mean recruitment rate of $0.53 \%$ year 1. Handroanthus ochraceus and Pseudopiptadenia contorta accounted for the highest number of recruits, with 5 individuals each. Tree turnover was relatively low $(1.08 \%)$ because of the lower number of recruits as compared to the number of dead trees. However, basal area turnover rate was relatively high $(2.14 \%)$ because of the balance between basal area loss $(1.37 \%)$ and gain $(2.92 \%)$. Net change rates were $-1.10 \%$ for abundance and $1.60 \%$ for basal area.

\section{Gradient analysis}

Detrended Correspondence Analysis suggested short gradients in both censuses. In 2005, the eigenvalue reached 0.27 for the first axis and 0.12 for the second (Figure 4). In 2010, the first axis was 0.28 whereas the second 0.07 .

\section{DISCUSSION}

The overall dynamic rates were below the mean as compared to the ones commonly found in Brazilian Seasonally Deciduous Forests (Werneck \& Franceschinelli, 2004; Marin et al., 2005; Carvalho \& Felfili, 2011). The decrease in abundance and density was due to the unbalance between mortality and recruitment. Higher mortality was evident in the smaller diameter classes as the first two classes accounted for $90 \%$ of the mortality. Conversely, surviving individuals were positively affected by biomass gain. In some undisturbed Tropical Forests, instability or disequilibrium periods involving mortality and recruitment are commonplace and part of their 
Table 1: Tree species list from a Northern Minas Gerais Seasonally Deciduous Forests remnant, sampled in two censuses (2005-2010). Species are ranked according to the Importance Value of 2005. Phytosociological parameters are: N: Number of Individuals, AB: basal area basal ( $\left.\mathrm{m}^{2}\right)$; DA: Absolute density (ind/ha); IV: importance value

\begin{tabular}{|c|c|c|c|c|c|c|c|c|c|c|}
\hline \multirow{2}{*}{ Species } & \multicolumn{4}{|c|}{2005} & \multicolumn{4}{|c|}{2010} & 2005 & 2010 \\
\hline & $\mathbf{N}$ & $\mathbf{A B}$ & DA & IV & $\mathbf{N}$ & $\mathbf{A B}$ & DA & IV & \multicolumn{2}{|c|}{ Position IV } \\
\hline Eugenia uniflora $\mathrm{L}$. & 184 & 1.216 & 460 & 15.754 & 172 & 1.166 & 430 & 15.097 & 1 & 1 \\
\hline Pseudopiptadenia contorta (DC.) G.P.Lewis \& M.P.Lima & 147 & 0.976 & 367.5 & 12.999 & 139 & 1.148 & 347.5 & 13.410 & 2 & 2 \\
\hline Poincianella pluviosa (DC.) L.P.Queiroz & 54 & 1.049 & 135 & 9.010 & 50 & 0.971 & 125 & 8.344 & 3 & 4 \\
\hline Handroanthus ochraceus (Cham.) Mattos & 76 & 0.629 & 190 & 7.619 & 80 & 0.814 & 200 & 8.581 & 4 & 3 \\
\hline Terminalia phaeocarpa Eichler & 32 & 0.463 & 80 & 5.444 & 31 & 0.453 & 77.5 & 5.332 & 5 & 5 \\
\hline Commiphora leptophloeos (Mart.) Gillett & 9 & 0.838 & 22.5 & 5.229 & 9 & 0.909 & 22.5 & 5.289 & 6 & 6 \\
\hline Handroanthus impetiginosus (Mart. ex DC.) Mattos & 35 & 0.420 & 87.5 & 4.811 & 35 & 0.472 & 87.5 & 5.006 & 7 & 7 \\
\hline Combretum duarteanum Cambess. & 30 & 0.103 & 75 & 3.592 & 22 & 0.077 & 55 & 2.984 & 8 & 8 \\
\hline Myracrodruon urundeuva Fr. All. & 9 & 0.309 & 22.5 & 2.929 & 9 & 0.330 & 22.5 & 2.964 & 9 & 9 \\
\hline Ruprechtia laxiflora Meisn. & 9 & 0.150 & 22.5 & 2.239 & 8 & 0.174 & 20 & 2.287 & 10 & 10 \\
\hline Coccoloba schwackeana Lindau & 8 & 0.097 & 20 & 1.962 & 8 & 0.101 & 20 & 1.996 & 11 & 11 \\
\hline Pterocarpus zehntneri Harms & 4 & 0.234 & 10 & 1.790 & 4 & 0.281 & 10 & 1.925 & 12 & 13 \\
\hline Parapiptadenia rigida (Benth.) Brenan & 10 & 0.026 & 25 & 1.748 & 9 & 0.032 & 22.5 & 1.968 & 13 & 12 \\
\hline Syagrus oleracea (Mrt.) Becc. & 5 & 0.121 & 12.5 & 1.733 & 5 & 0.122 & 12.5 & 1.734 & 14 & 17 \\
\hline Ceiba pubiflora (A.St.-Hil.) K.Schum. & 3 & 0.228 & 7.5 & 1.715 & 3 & 0.254 & 7.5 & 1.765 & 15 & 14 \\
\hline Tabebuia reticulata A.H.Gentry & 9 & 0.071 & 22.5 & 1.701 & 9 & 0.077 & 22.5 & 1.750 & 16 & 15 \\
\hline Anadenanthera colubrina (Vell.) Brenan & 6 & 0.184 & 15 & 1.664 & 6 & 0.212 & 15 & 1.742 & 17 & 16 \\
\hline Fridericia bahiensis (Schauer ex. DC.) L.G.Lohmann & 13 & 0.061 & 32.5 & 1.646 & 11 & 0.062 & 27.5 & 1.588 & 18 & 18 \\
\hline Machaerium acutifolium Vogel & 6 & 0.062 & 15 & 1.327 & 4 & 0.123 & 10 & 1.289 & 19 & 21 \\
\hline Sapium obovatum Klotzsch ex Müll.Arg. & 5 & 0.014 & 12.5 & 1.268 & 5 & 0.014 & 12.5 & 1.298 & 20 & 20 \\
\hline Lafoensia vandelliana Cham. \& Schltdl. & 11 & 0.038 & 27.5 & 1.257 & 11 & 0.037 & 27.5 & 1.288 & 21 & 22 \\
\hline Sweetia fruticosa Spreng. & 4 & 0.061 & 10 & 1.229 & 4 & 0.068 & 10 & 1.266 & 22 & 23 \\
\hline Casearia selloana Eichl. & 5 & 0.031 & 12.5 & 1.146 & 5 & 0.035 & 12.5 & 1.183 & 23 & 24 \\
\hline Luetzelburgia andradelimae H.C.Lima & 4 & 0.084 & 10 & 1.136 & 4 & 0.134 & 10 & 1.332 & 24 & 19 \\
\hline Cnidoscolus oligandrus (Müll.Arg.) Pax & 3 & 0.020 & 7.5 & 0.811 & 3 & 0.029 & 7.5 & 0.861 & 25 & 25 \\
\hline Mimosa tenuiflora (Willd.) Poiret & 6 & 0.022 & 15 & 0.763 & 4 & 0.026 & 10 & 0.698 & 26 & 28 \\
\hline Randia armata $(\mathrm{Sw}.) \mathrm{DC}$. & 3 & 0.007 & 7.5 & 0.753 & 3 & 0.008 & 7.5 & 0.776 & 27 & 27 \\
\hline Auxemma oncocalyx (Allemão) Taub. & 5 & 0.015 & 12.5 & 0.686 & 6 & 0.023 & 15 & 0.784 & 28 & 26 \\
\hline Leucochloron limae Barneby \& J.W.Grimes & 2 & 0.029 & 5 & 0.609 & 1 & 0.029 & 2.5 & 0.364 & 29 & 31 \\
\hline Machaerium sp nova & 2 & 0.020 & 5 & 0.571 & 1 & 0.018 & 2.5 & 0.321 & 30 & 33 \\
\hline Ptilochaeta bahiensis Turcz. & 3 & 0.006 & 7.5 & 0.556 & 3 & 0.007 & 7.5 & 0.574 & 31 & 29 \\
\hline Terminalia fagifolia Mart. & 2 & 0.006 & 5 & 0.507 & 1 & 0.007 & 2.5 & 0.277 & 32 & 39 \\
\hline
\end{tabular}




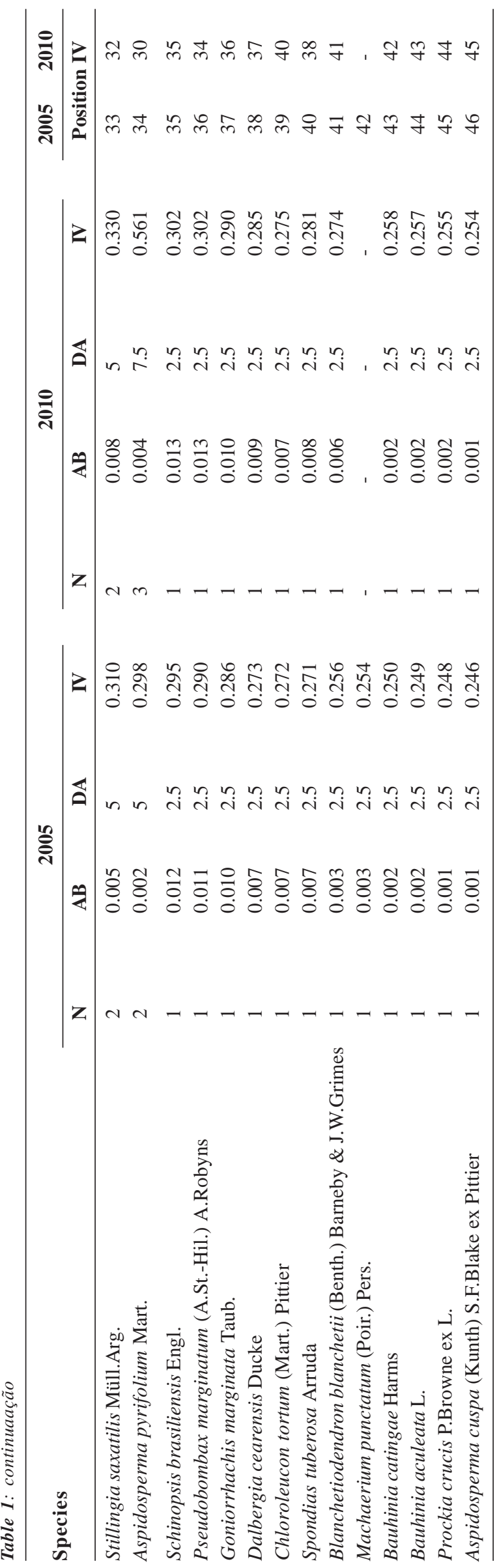

Table 2: Diversity, Structural and Dynamics parameters of two censuses (2005 - 2010) from a Northern Minas Gerais Seasonally Deciduous Forest remant

\begin{tabular}{lll}
\hline Parameter & $\mathbf{2 0 0 5}$ & $\mathbf{2 0 1 0}$ \\
\hline Diversity & 46 & 45 \\
Richness (S) & 2.62 & 2.60 \\
Shannon-Wienner Index (H') [nats ind $\left.{ }^{-1}\right]$ & 0.683 & 0.682 \\
\hline Eveness (J') & & \\
\hline Structure & 1845 & 1702.5 \\
Density (ind/ha) & 7.66 & 8.30 \\
Basal area (m $\left.{ }^{2}\right)$ & & \\
\hline Dynamics & - & 1.64 \\
Mortality (\% year $\left.{ }^{-1}\right)$ & - & 0.53 \\
Recruitment (\% ano $\left.{ }^{-1}\right)$ & - & 1.08 \\
Abundance turnover (\%) & - & 2.14 \\
Basal area turnover (\%) & - & 1.37 \\
Basal area Loss (\%) & - & 2.92 \\
Basal area Gain (\%) & - & -1.10 \\
Net Change - Abundance) (\%) & - & 1.60 \\
Net Change - Basal area (\%) & & \\
\hline
\end{tabular}

rhythmic cycles and can be illustrated by alternating periods of higher and lower mortality or recruitment, biomass and density (Swaine 1990; Phillips et al., 1994; Felfili, 1995; Sheil et al., 2000; Garcia et al., 2015). Among several candidate factors responsible for such tree community disequilibrium, disturbances can be highlighted as they are commonly the main cause of instability in Tropical Forests (Condit et al., 2006; Santos et al., 2017). High mortality rates in smaller classes has been reported for Tropical Forest submitted to natural (e.g. flooding, natural gaps, storms, climatic instability) or anthropic (fragmentation and edge effect-related processes, selective logging, fire) perturbation (Felfili, 1995; Oliveira-Filho et al., 1997; Taylor et al., 1996; Kellman et al., 1998; Guilherme et al., 2004; Werneck \& Franceschinelli, 2004; Van Den Berg et al., 2012; Santos et al., 2017). In Seasonally Deciduous Forests, water stress play a role as a natural disturbance, determining forest dynamics by influencing mortality in the smaller size classes once smaller individuals are more prone to climate seasonality (Condit et al., 1995; Santos et al., 2017).

Richness as reported here is within the range usually found for Neotropical Dry Forests (Gentry, 1995). This is also similar as compared to other studies in Brazilian Seasonal Deciduous Forests, such as the one reported by Santos et al., (2011) in Juvenilia (47 species). Contrasting ranges in species richness can be found throughout these formations such as the higher richness reported by Apgaua et al., (2014 a; b) in the same region (79 species) or lower richness as in Silva \& Scariot (2003) in the Rio Paraná basin, Goias state (36 species). Here, no new species in the interval was recorded whereas there 


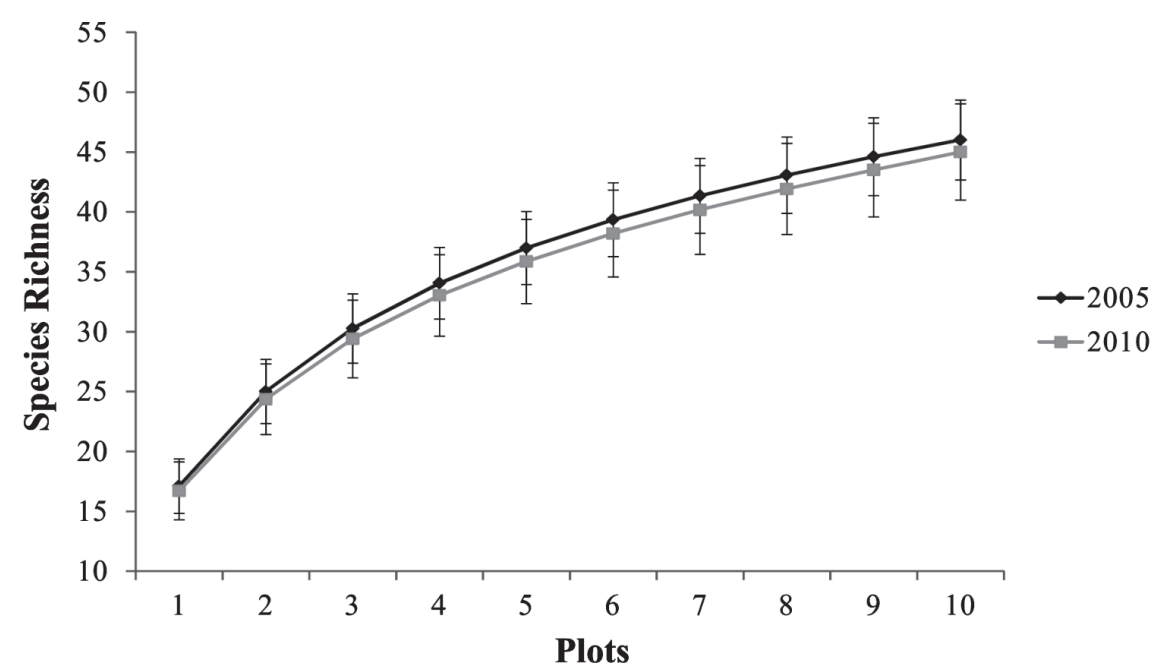

Figure 1: Species accumulation curves of a 5-year long-term study (2005-2010) from a Northern Minas Gerais state Seasonally Deciduous Forest remnant.

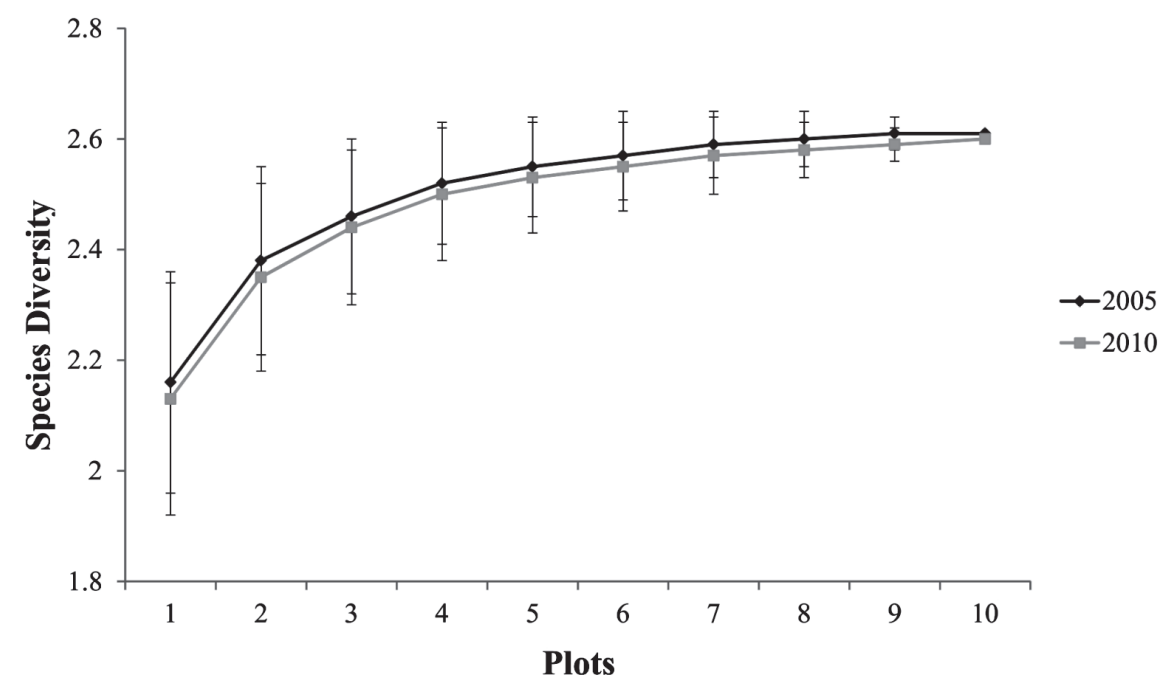

Figure 2: Diversity (Shannon Index) accumulation curves of a 5-year long-term study (2005-2010) from a Northern Minas Gerais state Seasonally Deciduous Forest remnant.

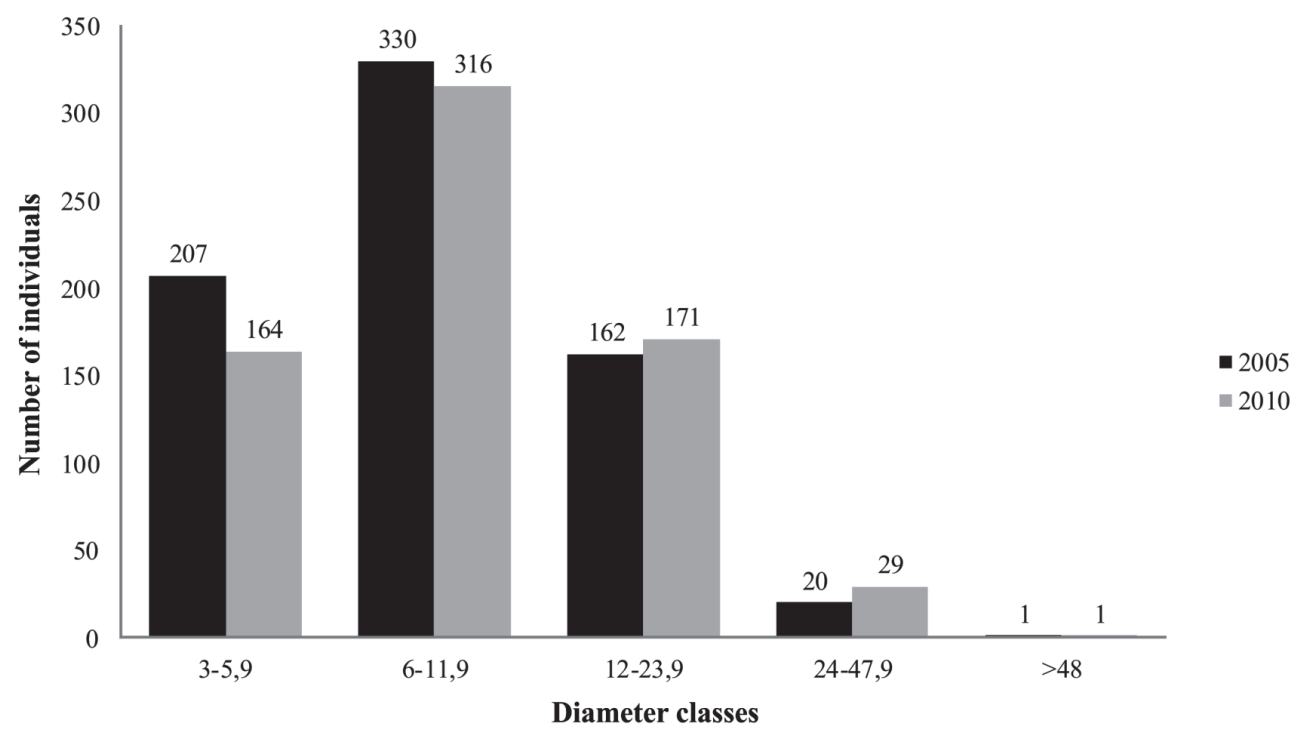

Figure 3: Size distribution by diameter classes ( $\mathrm{cm}$ ) of the trees sampled in a 5-year interval (2005-2010) in a Northern Minas Gerais state Seasonally Deciduous Forest remnant. 

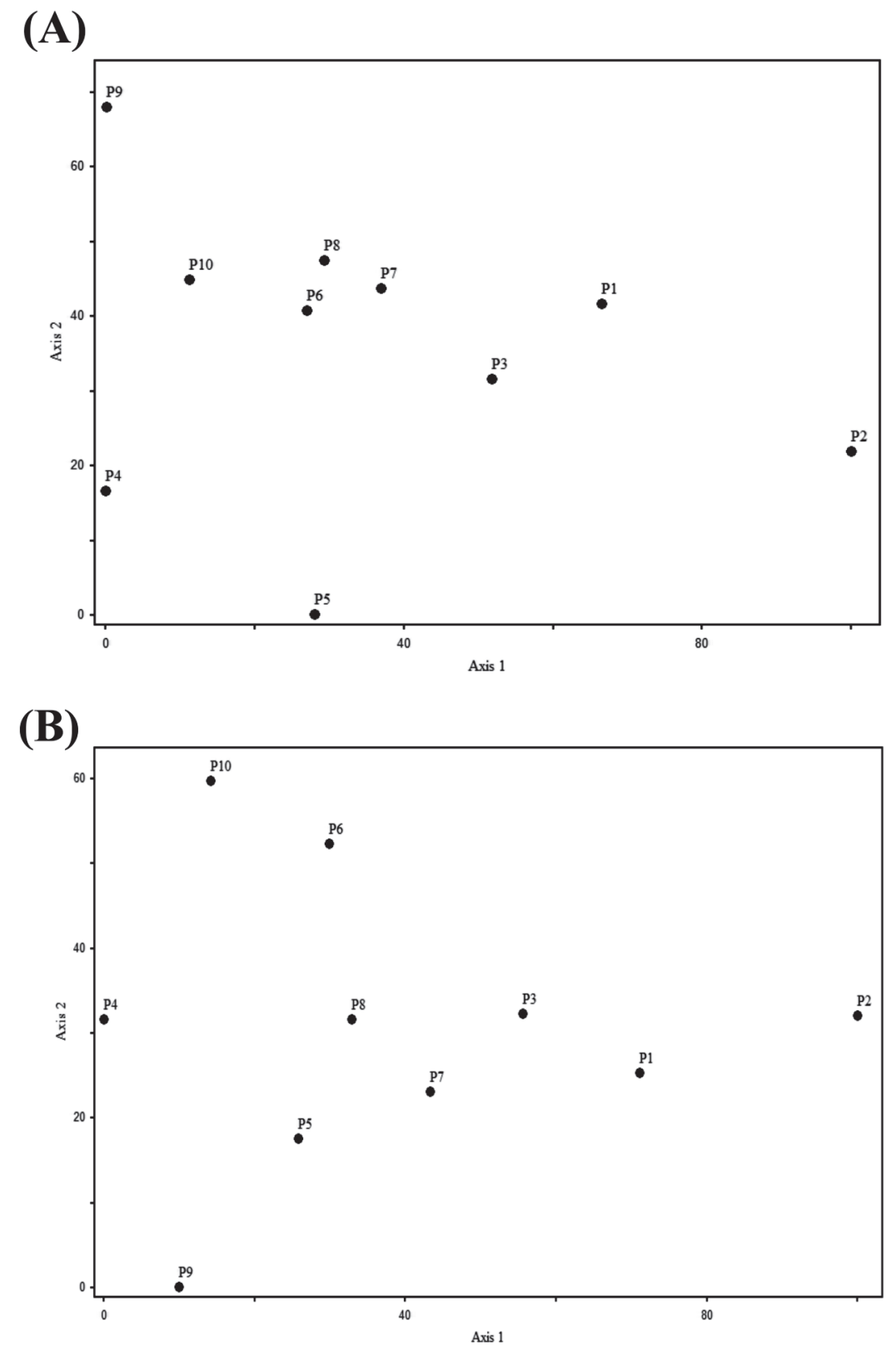

Figure 4: Abundance-based Dentrended Correspondence Analysis (DCA) ordination plot of two censuses (A - 2005; B - 2010) carried out in a Northern Minas Gerais state Seasonally Deciduous Forest remnant.

was the loss of a single species (one individual), Machaerium punctatum (Poir.) Pers in the sampling interval considered. According to Werneck et al., (2000), in Tropical Forests, species loss and gain are associated to the less abundant species in the community.

In practical terms, no significant changes occurred along the ranking concerning the main species in terms of IV. Only a single position was changed involving the exchange between P. pluviosa ( $3^{\mathrm{a}}$ in 2005 to $4^{\mathrm{a}}$ in 2010) and H. ochraceus ( $4^{\mathrm{a}}$ in 2005 to $3^{\mathrm{a}}$ in 2010). The drop of one position of P. pluviosa can be attributed to the loss of four large-sized trees and no recruitment for this species that is, decrease in basal area and abundance as directly reflected by density and dominance. On the opposite way, showing increasing density and basal area, H. ochraceus lost only one and gained five individuals, rising one position in the IV rank. In the present case, the highranked species in terms of IV such as Eugenia uniflora, Poincianella pluviosa, Handroanthus ochraceus, Combretum duarteanum and Myracrodruon urundeuva can be commonly found in Caatinga and Cerrado and, according to Santos et al., (2011), this may be related to their occurrence in a transition zone in the overlap of both domains.

Shannon-Wiener diversity values in both censuses were inferior as compared to other studies in Brazilian Seasonally Deciduous Forests. However, sampling issues can easily bias this type of diversity metric and thus, 
comparison involving studies with distinct sampling effort and designs, as in the present case, must be interpreted carefully (Magurran 2004). Pielou evenness remained nearly unaltered and indicated strong dominance in the tree community as illustrated by E. uniflora, $P$. contorta, P. pluviosa, H. ochraceus e C. leptophloeos which pooled, accounted for $60 \%$ of the overall dominance. Seasonally Deciduous Forests generally hold high dominance, usually triggered by water stress, since it acts as an environmental filter favoring species better adapted to climatic seasonality (Carvalho \& Felfili, 2011; Coyle et al., 2014; Santos et al., 2017).

Short eigenvalues (<0.5 sensu Ter Braak, 1995) as displayed by DCA analyses in both censuses suggest low species replacement along this tree community. Such outcome is likely to be related to the strong dominance presented in the community (Kent \& Coker, 1992). Furthermore, even with the structural (such as the biomass gain and density loss) as well as the demographic (such as the mortality higher than recruitment) variations, the similar configuration of both DCA's suggest low temporal species turnover during the interval, reflecting in a community remaining relatively stable.

\section{CONCLUSIONS}

The data show that in the five years comprised by the sampling interval there were small changes in the structure of the tree community.

There were no significant differences between the richness, diversity and Pielou evenness.

The most representative species in the community, considering their IV, also did not change significantly. The distribution of individuals in diametric classes, on the other hand, showed small differences between the two intervals.

The community also had a higher mortality rate than the recruitment rate. However, these results were not so discrepant as to be considered representative of major changes in the community, which requires a longer followup time to verify how these patterns behave for long time periods.

Conservation of these environments is necessary in order to allow long-term studies and monitoring of these communities and consequently, for a better understanding of the dynamics and structural processes concerning Seasonally Deciduous Forests.

\section{REFERENCES}

Apgaua DMG, Coelho PA, Santos RM, Santos PF \& Oliveira-Filho AT (2014a) Tree community structure in a Seasonally Dry Tropical Forest remnant, Brazil. Cerne, 20:173-182.
Apgaua DMG, Pereira DGS, Santos RM, Menino GCO, Pires GG, Fontes MAL \& TNG DYP (2015) Floristic variation within Seasonally Dry Tropical Forests of the Caatinga Biogeographic Domain, Brazil, and its conservation implications. International Forestry Review, 17:33-44.

Apgaua DMG, Santos RM, Pereira DGS, Menino GCO, Pires GG, Fontes MAL \& Tng DYP (2014b) Beta-diversity in seasonally dry tropical forests (SDTF) in the Caatinga Biogeographic Domain, Brazil, and its implications for conservation. Biodiversity and Conservation, 23:217-232.

Carvalho FA \& Felfili JM (2011) Variações temporais na comunidade arbórea de uma floresta decidual sobre afloramentos calcários no Brasil Central: composição, estrutura e diversidade florística. Acta Botanica Brasilica, 25:203-214.

Cavaleri MA, Reed SC, Smith WK \& Wood TE (2015) Urgent need for warming experiments in tropical forests. Global Change Biology, 21:2111-2121.

Condit R, Ashton P, Bunyavejchewin S, Dattaraja HS, Davies S, Esufali S \& Zillio T (2006) The importance of demographic niches to tree diversity. Science, 313:98-101.

Condit R, Hubbell SP \& Foster RB (1995) Mortality rates of 205 Neotropical tree and shrub species and the impact of a severe drought. Ecological Monographs, 65:419-439.

Coyle JR, Halliday FW, Lopez BE, Palmquist KA, Wilfahrt PA \& Hurlbert AH (2014) Using trait and phylogenetic diversity to evaluate the generality of the stress-dominance hypothesis in eastern North American tree communities. Ecography, 37:814826 .

Felfili JM (1995) Growth, recruitment and mortality in Gama gallery forest in central Brazil over a six-year period (19851991). Journal of Tropical Ecology, 11:67-83.

Garcia PO, Santos RM, Fontes MAL, Carvalho WAC, Menino GCO, Pereira DGS, Morel JD, Coelho PA, Pires GG, Santos PF, Brandão MM, Almeida HS, Apgaua DMG, Benício MHM \& Oliveira Filho AT (2015) Florestas ciliares apresentam dinâmica uniforme? In: Davide AC \& Botelho SA (Eds.) Fundamentos e métodos de restauração de ecossistemas florestais: 25 anos de experiência em matas ciliares. Lavras, Editora UFLA. p. 3372 .

Gentry AH (1995) Diversity and floristic composition of neotropical dry forests. In: Bullock SH, Mooney HA \& Medina E (Eds.) Seasonally dry tropical forests. Cambridge, Cambridge University Press. p.146-194.

Guilherme FAG, Oliveira Filho AT, Appolinário V \& Bearzoti E (2004) Effects of flooding regime and woody bamboos on tree community dynamics in a section of tropical semideciduous forest in South-Eastern Brazil. Plant Ecology, 174:19-36.

Instituto Brasileiro de Geografia e Estatística - IBGE (2012) Manual Técnico da Vegetação Brasileira. Rio de Janeiro, IBGE. $275 \mathrm{p}$.

Kellman M, Tackaberry R \& Rigg L (1998) Structure and function in two tropical gallery forest communities: implications for forest conservation in fragmented systems. Journal of Applied Ecology, 35:195-206.

Kent M \& Coker P (1992) Vegetation description and analysis, a practical approach. London, Belhaven. 363p.

Korning J \& Balslev H (1994) Growth and mortality of trees in Amazonian tropical rain forest in Ecuador. Journal of Vegetation Science, 4:77-86.

Magurran AE (2004) Measuring biological diversity. Oxford, Blackwell Science. 256p. 
Marin GC, Nygard R, Rivas BG \& Oden PC (2005) Stand dynamics and basal area change in a tropical dry forest in Nicaragua Forest Ecology and Management, 208:63-75.

McCune B \& Mefford MJ (2006) PC-ORD: Multivariate analysis of ecological data. version 5.0. Glaneden Beach, MjM Solfware Desing. 40p.

Murphy BP \& Bowman DMJS (2012) What controls the distribution of tropical forest and savanna? Ecology Letters, 15:748-758.

Murphy PG \& Lugo AE (1986) Ecology of tropical dry forest. Annual Review of Ecology and Systematics, 17:67-88.

Oldeman RAA (1990) Forests: elements of silvology. Berlin, Springer-Verlag. 624 p.

Oliveira-Filho AT, Mello JM \& Scolforo JRS (1997) Effects of past disturbance and edges on tree community structure and dynamics within a fragment of tropical semideciduous forest in south-eastern Brazil over a five-year period (1987-1992). Plant Ecology, 131:45-66.

Pennington RT, Lavin M \& Oliveira-Filho AT (2009) Woody plant diversity, evolution, and ecology in the tropics perspectives from seasonally dry tropical forests. Annual Review of Ecology, Evolution and Systematics, 40:37-57.

Pennington RT, Lewis GP \& Ratter JA (2006) An overview of the plant diversity, biogeography and conservation of neotropical savannas and seasonally dry forests. In: Pennington RT, Lewis GP \& Ratter JA (Eds.) Neotropical savannas and dry forests: plant diversity, biogeography, and conservation. Oxford, Taylor \& Francis CRC Press. p. 01-29.

Phillips OL, Hall P, Gentry AH, Sawyer SA \& Vasquez M (1994) Dynamics and species richness of tropical rainforests. Proceedings of the National Academy of Sciences of the United States of America, 91:2805-2809.

Santos PF, Garcia PO, Santos RM, Morel JD, Benício MHM, Apgaua DMG \& TNG DYP (2017) Temporal changes in tree community structure and richness in a seasonally dry tropical forest in Minas Gerais, southeastern Brazil. Bosque, 38:537-545.

Santos RM, Barbosa ACMC, Almeida HS, Vieira FA, Santos PF, Carvalho DA \& Oliveira-Filho AT (2011) Estrutura e florística de um remanescente de caatinga arbórea em Juvenília, norte de Minas Gerais, Brasil. Cerne, 17:247-258.

Santos RM, Oliveira-Filho AT, Eisenlohr PV, Queiroz LP, Cardoso DBOS \& Rodal MJN (2012) Identity and relationships of the Arboreal Caatinga among other floristic units of seasonally dry tropical forests (SDTFs) of north-eastern and Central Brazil. Ecology and Evolution, 2:409-428.
Santos RM, Vieira FA, Fagundes M, Nunes YRF \& Gusmão E (2007) Riqueza e similaridade florística de oito remanescentes florestais no norte de Minas Gerais, Brasil. Revista Árvore, $31: 135-144$.

Santos RM, Vieira FA, Santos PF, Morais VM \& Medeiros MA (2008) Estrutura e florística de um remanescente florestal na Fazenda Ribeirão, município de Juvenília, MG, Brasil. Revista Caatinga, 21:154-162.

Sheil D, Burslem DFRP \& Alder D (1995) The interpretation and misinterpretation of mortality rate measures. Journal of Ecology, $83: 331-333$

Sheil D, Jennings S \& Savill P (2000) Long-term permanent plot observations of vegetation dynamics in Budongo, a Ugandan rain forest. Journal of Tropical Ecology, 16:765-800.

Silva LA \& Scariot A (2003) Composição florística e estrutura da comunidade arbórea em uma floresta estacional decidual em afloramento calcário: fazenda São José, São Domingos, GO, Bacia do Rio Paranã. Acta Botanica Brasilica, 17:305-313.

Swaine MD (1990) Population dynamics of tree species in tropical forests. In: Holm-Nielsen LB, Nielsen IC \& Balslev H (Eds.) Tropical forest: botanical dynamics, speciation and diversity. London, Academic Press. p.101-110.

Taylor DM, Hamilton AC, Whyatt JD, Mucunguzi P \& BukenyaZiraba RB (1996) Stand dynamics in Mpanga Research Forest Reserve, Uganda, 1968-1993. Journal of Tropical Ecology, 12:583-597.

Ter Braak CJF (1995) Ordination. In: Jongman RHG, Ter Braak CJF \& Van Tongeren O (Eds.) Data analysis in community and landscape ecology. Cambridge, Cambridge University. p.91-173.

Van Den Berg E, Chazdon RL \& Correa BS (2012) Tree growth and death in a tropical gallery forest in Brazil: understanding the relationships among size, growth, and survivorship for understory and canopy dominant species. Plant Ecology, 213:1081-1092.

Werneck M \& Franceschinelli EV (2004) Dynamics of a dry forest fragment after the exclusion of human disturbance in southeastern Brazil. Plant Ecology, 174:337-346.

Werneck MS, Franceschinelli EV \& Tameirão-Neto E (2000) Mudanças na florística e estrutura de uma floresta decídua durante um período de 4 anos (1994-1998), na região do triângulo mineiro, MG. Revista Brasileira de Botânica, 23:401-413. 